\title{
PENGARUH FORTIFIKASI OLAHAN KEDELAI DAN PROSES PENGGORENGAN TERHADAP SIFAT FISIKOKIMIA DAN SENSORIS KERIPIK TORTILA DARI JAGUNG DAN MOCAF
}

\section{THE EFFECT OF SOYBEAN-BASED PRODUCTS FORTIFICATION AND FRYING PROCESS ON PHYSICOCHEMICAL AND SENSORY PROPERTIES OF TORTILLA CHIPS FROM CORN AND MOCAF}

\author{
Nok Afifah*, Enny Sholichah, Lista Eka Yulianti \\ ${ }^{1}$ Pusat Penelitian Teknologi Tepat Guna - LIPI, Jl. KS Tubun No. 5 Subang 41213, \\ *E-mail kontributor utama: syabiljafa2008@gmail.com
}

\begin{abstract}
ABSTRAK
Keripik tortila dibuat dengan menambahkan produk olahan kedelai untuk meningkatkan nilai gizinya. Produk tortila diproduksi dengan mencampur mocaf, tepung jagung, maizena, dan tepung beras dengan fortifkasi produk berbasis kedelai, yaitu kedelai kukus, tempe, dan tahu, dan digoreng dalam minyak sayur selama 20 detik. Tujuan penelitian ini untuk mengevaluasi pengaruh jenis bahan fortifikasi dan proses penggorengan terhadap sifat fisikokimia dan sensoris keripik tortila. Hasil penelitan menunjukkan bahwa proses penggorengan menurunkan kadar air dan menaikkan kandungan lemak dan parameter warna keripik. Dibandingkan dengan perlakuan kontrol, fortifikasi olahan kedelai meningkatkan kadar protein, lemak, abu, dan serat pangan keripik tortila berturut-turut sebesar 32-84\%,3-18\%, 65-91\%, $3-10 \%$. Fortifikasi juga menaikkan warna kemerahan dan kekuningan keripik, serta menurunkan daya patahnya. Hasil organoleptik menunjukkan bahwa fortifikasi olahan kedelai meningkatkan tingkat kesukaan panelis untuk parameter warna, tekstur, rasa, dan penerimaan keseluruhan. Fortifikasi tempe menghasilkan tingkat penerimaan keripik tortila tertinggi.
\end{abstract}

Kata kunci: jagung, kedelai, mocaf, penggorengan,tortila

\section{ABSTRACT}

The tortilla chips were made by adding soybean-based products to increase their nutritional value. They were prepared by mixing modified cassava flour, corn flour, corn starch, and rice flour with soybeanbased fortification products, namely boiled soybean, tempeh, and tofu, and fried in vegetable oil for 20 seconds. The effects of different fortification and frying process on the physicochemical and sensory properties of tortilla chips were evaluated. The results indicated that the frying process decreased moisture content and increased fat content and color parameters of chips. Compared to the control treatment, the fortification increased in protein, fat, dietary fiber, and ash content of tortilla chips of 32$84 \%, 3-18 \%, 65-91 \%, 3-10 \%$, respectively. In addition, fortification increased in redness-yellowness of chips and decreased their fractur-ability. The sensory results showed that fortification increased the consumers' preference in color, texture, taste, and overall parameters. The fortification with tempeh resulted in the highest acceptability of tortilla chips.

Keywords: corn, frying, mocaf, soybean, tortilla

\section{PENDAHULUAN}

M akanan ringan telah menjadi hal penting di seluruh dunia dalam beberapa tahun terakhir dan bahkan sekarang menjadi bagian dari budaya. Biasanya, makanan ringan berupa makanan padat kalori dengan kandungan karbohidrat dan lemak yang tinggi (Martinez et al., 2016). Keripik jagung dan keripik tortilla merupakan $80 \%$ dari makanan ringan 
berbasis jagung yang dikonsumsi di seluruh dunia (Rababah et al., 2012). Keripik tortila umumnya diproduksi melalui proses nikstamalisasi menggunakan alkali untuk menghasilkan masa jagung (Kawas dan Moreira, 2001)

Selain jagung, bahan panganlokal yang biasa digunakan sebagai sumber karbohidrat antara lain ubi kayu dan beras. Ketiga jenis bahan tersebut memiliki angka produksi tertinggi di Indonesia. Pada tahun 2015, produksi beras, ubi kayu, dan jagung secara berurutan adalah 75.397.841 ton, 21.801.415 ton, dan 19.612.435 ton (BPS, 2016). Ubi kayu dapat diolah menjadi mocaf (modified cassava flour) melalui proses fermentasi. Mocaf mempunyai peluang yang tinggi untuk mensubtitusi tepung jagung karena tingkat produksi bahan bakunya lebih tinggi, harganya lebih murah, dan mempunyai kandungan serat pangan yang cukup tinggi yaitu 9,58\% (Ratnawati et al., 2019)

Tren industri makanan saat ini adalah menghasilkan makanan ringan yang lebih bergizi (Martinez et al, 2016). Protein menjadi salah satu nutrisi dalam makanan ringan yang mendapat perhatian beberapa penelitian (Rababah et al., 2012). Penggunaan sumber protein yang murah dan tersedia telah menjadi fokus utama penelitian dalam beberapa tahun terakhir. Kedelai dan olahannya telah digunakan untuk meningkatkan kualitaskeripik tortila (Syafutri dan Lidiasari, 2014; Chabbra et al., 2017; Andriyani et al., 2017; dan Karneta et al., 2018).

Asmoro, et al. (2017) melaporkan keripik tortila dari jagung pipil yang paling diterima secara organoleptik adalah dengan subtitusi mocaf $15 \%$. Karneta et al. (2018) mempelajari pengaruh fortifikasi tepung kedelai, tepung tempe, dan tepung ampas tahu terhadap kadar proksimat dan organoleptik keripik tortiladari jagung pipil, dimana perlakuan terbaik adalah pada fortifikasi tepung kedelai 30\%. Chabbra et al.(2017) melaporkan pembuatan keripik tortila dari komposit tepung jagung:pearl millet.kedelai dengan perbandingan 60:30:10 dan difortifikasi tepung labu sampai $20 \%$.

Pada pembuatan tepung jagung, selain produk tepung juga dihasilkan menir yang belum banyak dimanfaatkan untuk olahan pangan. Bagaimanapun belum ada penelitian yang melaporkan pembuatan keripik tortila dari komposit menir jagung dan mocaf dengan fortifikasi olahan kedelai. Meskipun nilai gizi dapat ditingkatkan, sifat teksturnya dapat menentukan penerimaan produk. Oleh karena itu, penelitian ini bertujuan untuk mempelajari pengaruh fortifikasi olahan kedelai dan proses penggorengan terhadap nilai gizi, tekstur, dan penerimanaan keripik tortila berbasis jagung dan mocaf.

\section{METODE PENELITIAN Bahan dan Alat}

Bahan yang digunakan dalam penelitian ini terdiri dari menir jagung yang diproduksi di Pilot Plant Tepung P2TTG sesuai prosedur yang dilaporkan (Ratnawati dan Afifah, 2018), maizena (Maizenaku, Egafood), mocaf (Mocaf Bandung, CV Karunia Maha Cipta), tepung beras putih (Rose Brand, Bumi Waras Group), baking powder, garam, minyak goreng sawit, dan biji kedelai, tempe, atau tahu yang diperoleh dari pasar tradisional.Alat yang digunakan untuk produksi tortila terdiri dari blender, mixer, alat pengukus, mesin pemadat adonan, dan mesin sheeting.

\section{Rancangan Percobaan dan Analisis Data}

Rancangan percobaan untuk penelitian ini adalah rancangan acak lengkap dengan satu faktor berupa jenis sumber protein sebagai fortifikan dengan tiga perlakuan (biji kedelai kukus, tempe, dan tahu) dengan 3 kali ulangan untuk setiap perlakuan. Sebagai kontrol adalah keripik tortila tanpa penambahan sumber protein.

Data yang diperoleh dari setiap pengujian dianalisis menggunakan software excel dan ANOVA menggunakan SPSS 13 . Perlakuan yang menunjukan pengaruh nyata $(p<0,05)$ dilanjutkan dengan uji Duncan. 


\section{Prosedur Penelitian}

Komposisi bahan (presentase terhadap berat total adonan) untuk pembuatan tortila terdiri dari mocaf $30 \%$, tepung (menir) jagung $15 \%$, maizena $15 \%$, tepung beras $8 \%$, garam $0,8 \%$, baking powder $0,2 \%$, dan sisanya air. Fortifikasi sumber protein berupa kedelai kukus/tempe/tahu sebanyak $13 \%$ terhadap total adonan. Biji kedelai direndam selama 4 jam dan dikupas kulit arinya. Biji kedelai/tempe/tahu dikukus selama 10 menit dan dihaluskan menggunakan blender dengan menambahkan air. Bubur tersebut di-mixer bersama dengan bahan-bahan lain sampai homogen. Adonan dikukus selama 20 menit, selanjutnya dimampatkan dalam ekstruder, dan dipipihkan menggunakan mesin sheeting-sleeting sampai ketebalan $0,2 \mathrm{~mm}$. Lembaran adonan dipotong-potong persegi $2 \times 2 \mathrm{~cm}$ dan dikeringkan di bawah sinar matahari. Penggorengan chips dilakukan pada suhu minyak goreng $180-190^{\circ} \mathrm{C}$ selama 20 detik.

\section{Analisis Produk}

Analisis proksimat (air, abu, dan lemak) dilakukan sesuai prosedur SNI 01-2891-1992 tentang cara uji makanan dan minuman (BSN, 1992), sedangkan kadar protein diukur dengan prinsip Dumas combustion (DuMaster Buchi D-480, Switzerland). Analisis warna menggunakan colormeter ( $\mathrm{NH} 3$ ) dimana pengukuran menggunakan skala CIE Lab dengan parameter $\mathrm{L}$ (lightness), a (merah-hijau) dan b (kuning-biru). Kerenyahan (fracturability) diukur menggunakan TA.XTPlus Texture Analyzer (Stable Micro Systems) pada pengaturan spherical ball probe P0.25, kecepatan tes $1 \mathrm{~mm} / \mathrm{s}$, jarak 3mm, trigger force $5 \mathrm{~g}$ (Chhabra et al., 2017). Kadar serat pangan dianalisis sesuai prosedur AOAC official method 985.29 (AOAC International, 2007.

Uji organoleptik keripik tortila meliputi rasa, warna, tekstur/kerenyahan, aroma, dan penerimaan keseluruhan. Evaluasi dilakukan dengan menggunakan panelis tak terlatih sebanyak 30 orang. Penilaian didasarkan pada tingkat kesukaan panelis dengan pemberian skoring yaitu skor 6 = sangat suka, skor $5=$ suka, skor $4=$ agak suka; skor $3=$ agak tidak suka, skor 2 = tidak suka dan skor $1=$ sangat tidak suka.

\section{HASIL DAN PEMBAHASAN}

Tortila yang dihasilkan dari setiap perlakuan yaitu penambahan sumber protein telah dilakukan pengujian proksimat (kadar air, abu, lemak dan protein), serat pangan, warna, kerenyahan dan uji organoleptik. Data yang diperoleh sebanyak 3 ulangan pada setiap perlakuan, selanjutnya dianalisis secara statistik dan disajikan sebagai nilai rata-rata yang dilengkapi dengan standar deviasi danhasil uji Duncun yang dicirikan dengan simbol huruf tercetak superscript.

\section{Analisis Proksimat}

Nilai rata-rata untuk kadar air, abu, lemak, dan protein tortila mentah (sebelum penggorengan) dan keripik tortila (setelah penggorengan) dapat dilihat pada Tabel 1 berikut. Fortifikan yaitu kedelai, tempe dan tahu dalam tortila secara nyata meningkatkan kadar air, abu, protein, dan lemak tortila mentah dibandingkan dengan perlakuan kontrol. Peningkatan tersebut karena ada penambahan kandungan air, abu, protein, dan lemak dari olahan kedelai. Kandungan protein tortila dengan fortifikasi tahu lebih rendah dibandingkan dengan fortifikasi biji kedelai dan tempe. Tahu mempunyai kadar protein lebih rendah dibandingkan biji kedelai dan tempe karena kandungan airnya cukup tinggi. Biji kedelai kukus, tempe, dan tahu yang digunakan dalam penelitian ini mempunyai kadar air berturut-turut 54,27\%, 40,91\%, dan $81,55 \%$, sedangkan kadar proteinnya berturut-turut sebesar $19,16 \%, 16,43 \%$, dan $9,50 \%$. Darmajana et al. (2015) melaporkan kadar air, abu, protein, dan lemak rendaman biji kedelai berturut-turut 59,42\%, 2,20\%, 13,42\%, dam 9,15\%, sedangkan tahu yang dihasilkan mempunyai kadar air, abu, protein, dan lemak sebesar $83,44 \%, 0,36 \%, 6,43 \%$, dan $6,14 \%$. 
Tabel 1. Kadar proksimat tortila mentah dan keripik tortila

\begin{tabular}{lcccc}
\hline Perlakuan & Air, \% & Abu, \%bk & Protein, \%bk & Lemak, \%bk \\
\hline \multicolumn{5}{c}{ TortilaMentah } \\
\hline Kontrol & $8,12 \pm 0,05^{\mathrm{B}}$ & $1,880 \pm 0,06^{\mathrm{B}}$ & $3,79 \pm 0,30^{\mathrm{C}}$ & $1,36 \pm 0,07^{\mathrm{D}}$ \\
\hline Kedelai & $9,10 \pm 0,82^{\mathrm{A}}$ & $2,11 \pm 0,11^{\mathrm{A}}$ & $6,85 \pm 0,62^{\mathrm{A}}$ & $3,87 \pm 0,31^{\mathrm{A}}$ \\
\hline Tempe & $9,29 \pm 0,42^{\mathrm{A}}$ & $2,07 \pm 0,03^{\mathrm{A}}$ & $6,78 \pm 0,28^{\mathrm{A}}$ & $3,36 \pm 0,10^{\mathrm{B}}$ \\
\hline Tahu & $9,31 \pm 0,37^{\mathrm{A}}$ & $2,04 \pm 0,09^{\mathrm{AB}}$ & $5,43 \pm 0,32^{\mathrm{B}}$ & $2,72 \pm 0,80^{\mathrm{C}}$ \\
\hline \multicolumn{5}{c}{ Keripik Tortila } \\
\hline Kontrol & $1,94 \pm 0,62^{\mathrm{b}}$ & $1,52 \pm 0,02^{\mathrm{a}}$ & $3,83 \pm 0,12^{\mathrm{c}}$ & $18,20 \pm 5,04^{\mathrm{a}}$ \\
\hline Kedelai & $2,48 \pm 0,18^{\mathrm{ab}}$ & $1,67 \pm 0,12^{\mathrm{a}}$ & $6,86 \pm 0,22^{\mathrm{a}}$ & $21,33 \pm 1,32^{\mathrm{a}}$ \\
\hline Tempe & $2,79 \pm 0,31^{\mathrm{a}}$ & $1,53 \pm 0,03^{\mathrm{a}}$ & $6,62 \pm 0,43^{\mathrm{a}}$ & $18,63 \pm 1,85^{\mathrm{a}}$ \\
\hline Tahu & $3,27 \pm 0,41^{\mathrm{a}}$ & $1,58 \pm 0,11^{\mathrm{a}}$ & $4,91 \pm 0,55^{\mathrm{b}}$ & $19,99 \pm 6,24^{\mathrm{a}}$ \\
\hline
\end{tabular}

Keterangan: Data (mean $\pm S D$ ) dihitung dari 3 ulangan. Data dianalisis dengan ANOVA dilanjutkan dengan uji Duncan. Huruf kapital superscript yang berbeda pada tiap kolom produk tortila mentah menunjukkan perbedaan nyata $(P<0,05)$. Huruf kecil superscript yang berbeda pada tiap kolom produk keripik tortila menunjukkan perbedaan nyata $(P<0,05)$

Setelah proses penggorengan tortila kontrol mempunyai kadar air dan protein nyata lebih rendah dibandingkan perlakuan dengan penambahan olahan kedelai. Kadar air keripik tortila berkisar 1,94\%-3,27\%, sebagaimana hasil yang dilaporkan oleh Kaur dan Aggarwal (2017) bahwa kadar air dan lemak keripik tortila sekitar 2\% dan 25\%. Proses penggorengan menyebabkan penurunan kadar air dan peningkatan kandungan lemak keripik tortila. Pada proses penggorengan terjadi proses perpindahan masa air dan minyak yang ditandai dengan hilangnya sejumlah air dari tortila dan terabsorbsinya minyak ke dalam tortila. Kawas dan Moreira (2001) menjelaskan laju kehilangan air dan absorpsi minyak pada tortila lebih cepat terjadi pada 15 detik pertama penggorengan. Kandungan protein keripik tortila dengan fortifikasi olahan kedelai lebih tinggi dibandingkan keripik tortila kontrol. Hasil ini sesuai dengan hasil Rababah et al. (2012) yang melakukan fortifikasi keripik jagung dengan 3-9\% isolat protein kedelai (ISP) dan tepung chickpea, dimana kadar protein meningkat dari $6,4 \%$ menjadi 6,8-10,5\% Karneta et al. (2018) melaporkan tortila yang difortifikasi tepung kedelai, tepung tempe dan tepung ampas tahu mempunyai kadar air berkisar antara 2,15-3,70\%, kadar abu 3,30-5,25\%, dan kadar protein 8,52-30,29\%. Standar nasional untuk keripik tortila belum ada, produk ini dapat didekatkan dengan SNI 2886:2015 tentang makanan ringan ekstrudat yang mensyaratkan kadar air maksimal 4\%, kadar lemak dengan proses penggorengan maksimal 38\%, dan kadar abu tidak larut asam maksimal 0,1\% (BSN, 2015). Berdasarkan Tabel 1 terlihat bahwa kadar air dan lemak keripik tortila masih memenuhi SNI tersebut, demikian juga dengan kadar abu tak larut asam yang nilainya berkisar antara0,02$0,03 \%$.

\section{Serat Pangan}

Serat pangan merupakan bagian dari makanan yang tidak dapat dicerna yang dapat menjaga kesehatan saluran pencernaan. Serat pangan rata-rata keripik tortila kontrol dan dengan fortifikasi olahan kedelai dapat dilihat pada Gambar 1. 


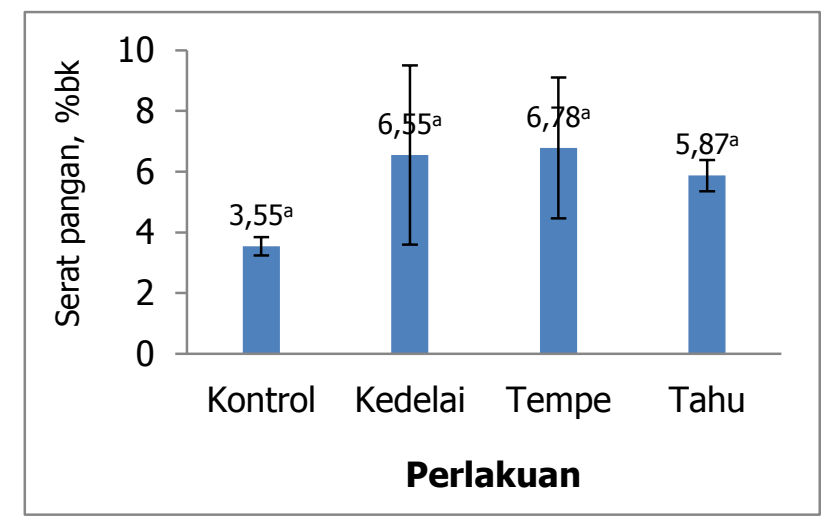

Gambar 1. Nilai serat pangan keripik tortila. Huruf superscript yang berbeda pada tiap diagram batang menunjukkan perbedaan nyata $(P<0,05)$

Serat pangan keripik tortila antar perlakuan tidak menunjukkan perbedaan yang nyata. Peningkatan nilai serat pangan keripik tortila pada perlakuan fortifikasi olahan kedelai dibandingkan perlakuan kontrol karena adanya kontribusi serat pangan dari bahan fortifikan. Kandungan serat pangan pada tepung kedelai sebesar 9,89\% (Ratnawati et al., 2019), sedangkan tempe berkisar 6,57-7,21\% (Astawan et al., 2013). Rohmayanti et al. (2019) melaporkan tortilla chips dengan perbandingan persentase masa jagung $36 \%$ : tepung ampas kecap $18,2 \%$ mempunyai kadar serat pangan sebesar $6,22 \%$ dengan kadar air $2,35 \%$, abu $5.78 \%$,lemak $19,94 \%$, dan protein $14,76 \%$.

\section{Warna}

Nilai rata-rata warna tortila sebelum dan setelah penggorengan pada berbagai perlakuan fortifikasi olahan kedelai dapat dilihat pada Tabel 2. Lembaran tortila mentahmenunjukkan perbedaan yang tidak nyata antar perlakuan untuk parameter lightness (L).Penambahan olahan kedelai menghasilkan produk tortila kering yang lebih kemerahan dan lebih kekuningan dibandingkan perlakuan kontrol. Perlakuan fortifikasi tempe menghasilkan tortila kering dengan nilai 'a' nyata lebih tinggi dibandingkan perlakuan lain. Perbedaan warna ini karena kontribusi warna dari bahan fortifikan. Tempe yang digunakan mempunyai nilai 'a', dan ' $b$ ' berturut-turut sebesar 8,99 dan 20,90, sedangkan tahu berturut-turut -0,57 dan 22,87. Widaningrum et al. (2005) menyatakan lemakatau minyak pada bahan pangan khususnyaproduk tepung-tepungan akan memberikanefek terhadap warna tepung yaitumeningkatnya warna kekuningan. Kacang kedelaimengandung zat warna karoten yang berkontrbusi memberikan warna kuning padatepung yang dihasilkan (Ratnawati et al., 2019). 
Tabel 2. Warna tortila mentah dan keripik tortila

\begin{tabular}{llrr}
\hline Perlakuan & Nilai 'L' & Nilai 'a' & Nilai 'b' \\
\hline \multicolumn{4}{c}{ Tortila Mentah } \\
\hline Kontrol & $54,56 \pm 1,35^{\mathrm{A}}$ & $3,59 \pm 0,28^{\mathrm{B}}$ & $15,21 \pm 0,70^{\mathrm{B}}$ \\
\hline Kedelai & $56,02 \pm 0,99^{\mathrm{A}}$ & $4,04 \pm 0,30^{\mathrm{B}}$ & $16,58 \pm 0,56^{\mathrm{AB}}$ \\
\hline Tempe & $54,26 \pm 1,05^{\mathrm{A}}$ & $5,24 \pm 0,17^{\mathrm{A}}$ & $17,68 \pm 1,00^{\mathrm{A}}$ \\
\hline Tahu & $55,89 \pm 0,92^{\mathrm{A}}$ & $3,68 \pm 0,22^{\mathrm{B}}$ & $16,98 \pm 0,78^{\mathrm{A}}$ \\
\hline \multicolumn{4}{c}{ Keripik $^{\mathrm{c}}$ Tortila } \\
Kontrol & $72,30 \pm 1,24^{\mathrm{a}}$ & $3,77 \pm 0,94^{\mathrm{bc}}$ & $17,71 \pm 1,77^{\mathrm{bc}}$ \\
\hline Kedelai & $69,01 \pm 1,14^{\mathrm{a}}$ & $4,84 \pm 0,68^{\mathrm{ab}}$ & $20,03 \pm \underline{0}, 14^{\mathrm{ab}}$ \\
\hline Tempe & $69,43 \pm 1,03^{\mathrm{a}}$ & $5,15 \underline{ \pm 0,75^{\mathrm{a}}}$ & $20,45 \pm 1,66^{\mathrm{a}}$ \\
\hline
\end{tabular}

Keterangan: Data (mean \pm SD) dihitung dari 3 ulangan. Data dianalisis dengan ANOVA dilanjutkan dengan uji Duncan. Huruf kapital superscript yang berbeda pada tiap kolom produk tortila mentah menunjukkan perbedaan nyata $(P<0,05)$. Huruf kecil superscript yang berbeda pada tiap kolom produk keripik tortila menunjukkan perbedaan nyata $(P<0,05)$

Keripik tortila mempunyai tren warna yang hampir sama dengan tortila mentah sebelum digoreng. Proses penggorengan meningkatkan nilai kecerahan (lightness) dan nilai ' $b$ ' tortila. Adedeji dan Ngadi (2011) menjelaskan perubahan warna selama penggorengan disebabkan adanya interaksi antara grup karbonil gula dan grup nucleophilic amino dari asam amino dan reaksi karamelisasi yang terjadi sebagai hasil pirolisis gula ketika produk terkena panas. Warna makanan yang digoreng ditentukan oleh kadar air, aktivitas air dan komposisi produk pangan, juga oleh kualitas minyak goreng dan instensitas panas. Peningkatan warna merah pada keripik jagung yang difortifikasi isolat protein kedelai dilaporkan oleh Rababah et al. (2012), dengan nilai 'a' sebesar 1,40 untuk kontrol dan 1,60 untuk keripik dengan fortifikan isolat protein kedelai $9 \%$.

\section{Profil Tekstur Fracturability (Daya Patah)}

Tekstur merupakan salah satu atribut utama makanan ringan. Nilai rata-rata fracturability (daya patah) keripik tortila pada berbagai perlakuan dapat dilihat pada Gambar 2. Fortifikasi olahan kedelai ke dalam formula keripik tortila menurunkan fracturability keripik tortila dibandingkan perlakuan kontrol meskipuntidak berbeda nyata. Semakin tinggi nilai daya patahnya, semakin keras produk tersebut.

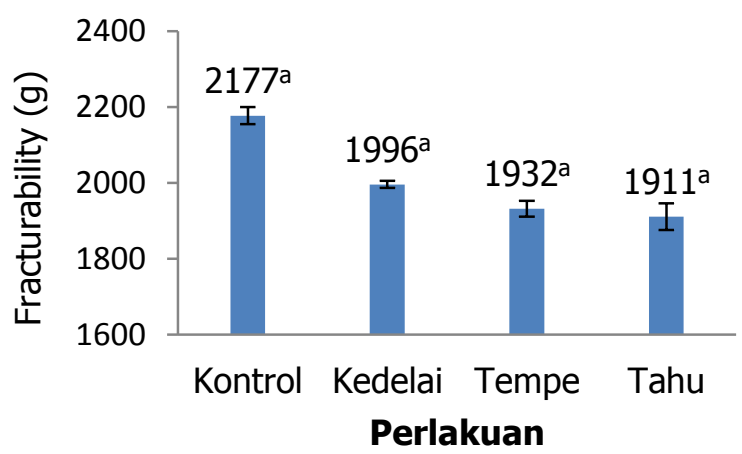

Gambar 2. Nilai fracturability (daya patah) keripik tortila. Huruf superscript yang berbeda pada tiap diagram batang menunjukkan perbedaan nyata $(P<0,05)$ 
Hasil yang sama dilaporkan oleh Rabahah et al. (2012) bahwa fortifikasi ISP dan tepung kacang chickpea menurunkan kekerasan dari keripik jagung dibandingkan keripik tanpa fortifikan. Penurunan ini bisa disebabkan oleh fortifikan membuat lebih banyak saluran dan sel udara, sehingga menciptakan struktur yang lebih mengembang, yang menyebabkan keripik lebih lunak sehingga lebih mudah dipatahkan. Kandungan protein pada kedelai membuat keripik yang lebih lunak.

\section{Sifat Sensoris}

Nilai rata-rata penerimaan keripik tortila berdasarkan tingkat kesukaan panelis disajikan pada Tabel 3. Fortifikasi olahan kedelai dalam formula tortila memberikan pengaruh yang berbeda nyata dibandingkan perlakuan kontrol untuk parmeter hedonik warna, tekstur (kerenyahan), dan penerimaan keseluruhan keripik tortila.

Tabel 3. Nilai penerimaan keripik tortila

\begin{tabular}{lccrcc}
\hline Perlakuan & Warna & Aroma & Kerenyahan & Rasa & Overall \\
\hline Kontrol & $4,09 \pm 0,75^{\mathrm{c}}$ & $4,56 \pm 0,86^{\mathrm{ab}}$ & $4,29 \pm 0,87^{\mathrm{b}}$ & $4,18 \pm 0,97^{\mathrm{b}}$ & $4,18 \pm 0,80^{\mathrm{b}}$ \\
\hline Kedelai & $4,59 \pm 0,78^{\mathrm{b}}$ & $4,44 \pm 0,82^{\mathrm{ab}}$ & $4,91 \pm 0,87^{\mathrm{a}}$ & $4,56 \pm 0,86^{\mathrm{ab}}$ & $4,74 \pm 0,62^{\mathrm{a}}$ \\
\hline Tempe & $5,06 \pm 0,65^{\mathrm{a}}$ & $4,65 \pm 0,85^{\mathrm{a}}$ & $5,21 \pm 0,84^{\mathrm{a}}$ & $4,74 \pm 0,86^{\mathrm{a}}$ & $4,88 \pm 0,81^{\mathrm{a}}$ \\
\hline Tahu & $4,50 \pm 1,08^{\mathrm{b}}$ & $4,15 \underline{ \pm 0,82^{\mathrm{b}}}$ & $5,06 \pm 0,95^{\mathrm{a}}$ & $4,47 \pm 0,83^{\mathrm{ab}}$ & $4,94 \underline{0} 0,81^{\mathrm{a}}$ \\
\hline
\end{tabular}

Keterangan: Data (mean \pm SD) dihitung dari 30 panelis. Data dianalisis dengan ANOVA dilanjutkan dengan uji Duncan. Huruf superscript yang berbeda pada tiap kolom menunjukkan perbedaan nyata $(P<0,05)$

Respon sensoris untuk parameter warna menunjukkan penambahan tempe dalam formula tortila memberikan skor kesukaan nyata lebih tinggi (nilai 5,06) dibandingkan perlakuan lain. Perlakuan kontrol mempunyai respon kesukaan warna paling rendah (nilai 4,09), artinya penambahan olahan kedelai meningkatkan tingkat kesukaan panelis terhadap warna produk. Fortifikasi olahan kedelai dalam formula tortila menyebabkan warna produk lebih kemerahan dan lebih kekuningan dibandingkan perlakuan kontrol seperti yang ditunjukkan Tabel 2. Hasil yang sama ditunjukkan oleh Karneta et al (2018), penambahan tepung kedelai, tepung tempe, dan tepung ampas tahu pada berbagai konsentrasi dalam formula tortila jagung memberikan respon hedonik warna tortila yang tidak berbeda nyata pada tingkat antara suka dan sangat suka.

Fortifikasi olahan kedelai memberikan skor yang tidak berbeda nyata dibandingkan perlakuan kontrol untuk respon sensoris aroma keripik tortila. Skor tertinggi (skor 4,65 ) diberikan panelis untuk keripik tortila dengan penambahan tempe. Semua perlakuan memberikan hasil yang dapat diterima panelis yang ditunjukkan dengan nilai antara agak suka hingga mendekati suka, artinya tortila dengan penambahan olahan kedelai memiliki aroma yang normal seperti aroma kontrol. Andriyani et al. (2017) menyatakan tempe memiliki aroma khas kedelai yaitu berbau langu atau apek, sehingga penambahannya dalam tortila harus dibatasi. Aroma langu yang biasanya muncul dari olahan kedelai tidak dirasakan oleh panelis pada tortila hasil penelitian ini karena adanya proses blanching olahan kedelai dalam produksi tortila. Menurut Christian (2017) proses blanching dilakukan untuk menginaktifasi enzim lipoksigenase yang menyebabkan off flavor pada olahan kedelai.

Respon sensoris hedonik untuk kerenyahan tortilla chips menunjukkan hasil yang berbeda tidak nyatauntuk perlakuan jenis fortifikan dengan tingkat kesukaan antara mendekati suka dan suka (nilai 4,91-5,21). Panelis memberikan skor nyata lebih rendah (nilai 4,29) untuk 
perlakuan kontrol dibandingkan perlakuan dengan penambahan olahan kedelai. Hasil ini sesuai dengan hasil pengujian tingkat daya patah (fracturability) pada Gambar 2 yang menunjukkan perlakuan kontrol memiliki kekerasan paling tinggi dibandingkan perlakuan lain. Karneta et al. (2018) melaporkan hasil yang sama, bahwa jenis fortifikan olahan kedelai tidak memberikan perbedaan nyata terhadap tingkat kesukaan panelis untuk parameter tekstur. Andriyani et al. (2017) lebih lanjut melaporkan bahwa peningkatan konsentrasi tempe dalam tortila jagung memberikan tingkat kesukaan panelis yang semakin meningkat terhadap kerenyahan tortila.

Penambahan olahan kedelai dalam formula tortila meningkatkan kesukaan panelis terhadap parameter rasa dibandingkan perlakuan kontrol meskipun tidak berbeda nyata,

kecuali untuk perlakuan fortifikasi tempe. Panelis memberikan respon hedonik rasa tortila terendah untuk perlakuan kontrol dengan nilai 4,18 dan tertinggi untuk perlakuan fortifikasi tempe dengan nilai 4,74. Andriyani et al. (2017) menunjukkan hasil yang sama bahwa penambahan tempe dalam tortila jagung menambah rasa gurih tortila.

Penilaian terhadap penerimaan keseluruhan (overall) keripik tortilamenunjukkan respon sensoris yang berbeda nyata untuk perlakuan kontrol (nilai 4,18), dan tidak berbeda nyata untuk tortila dengan berbagai jenis fortifikan (nilai antara 4,74-4,94). Hal tersebut menunjukkan bahwa penambahan olahan kedelai dalam formula tortila meningkatkan tingkat penerimaan produk ini. Hasil ini sesuai dengan tingkat kesukaan yang diberikan oleh panelis terhadap warna, kerenyahan, dan rasa keripik tortila.

\section{KESIMPULAN}

Keripik tortila telah diproduksi dengan mencampur tepung jagung, mocaf, dan beras dengan fortifikasi produk olahan kedelai (kedelai kukus, tempe, dan tahu) yang digoreng selama 20 detik. Proses penggorengan menurunkan kadar airchips dan meningkatkan kadar lemak dan parameter warna terutama lightness-nya. Fortifikasi produkolahan kedelai pada keripik tortila meningkatkan kandungan protein, lemak, serat pangan, abu, dan warna, serta menurunkan daya patahnya dibandingkan produk keripik tortila tanpa fortifikasi. Fortifikasi olahan kedelai meningkatkan tingkat kesukaan panelis untuk parameter warna, tekstur, rasa, dan penerimaan keseluruhan. Keripik tortila dengan fortifikasi tempe merupakan produk dengan tingkat keberterimaan tertinggi berdasarkan sifat fisikokimia dan tingkat kesukaan panelis.

\section{UCAPAN TERIMA KASIH}

Kami mengucapkan terima kasih kepada tim penelitian "Penerapan Teknologi Pembuatan Mocatilla Chips di Kabupaten Subang" dan Lembaga Ilmu Pengetahuan Indonesia yang telah mendanai kegiatan penelitian ini serta kepada P2 TTG-LIPI yang telah menyediakan sarana dan prasana dalam penelitian ini.

\section{DAFTAR PUSTAKA}

Adedeji, A. A. dan Ngadi, M. O. 2011.Physicochemical Changes of Foods During Rying: Novel Evaluation Techniques and Effects of Process Parameters. https://www.researchgate.net/publication/271840558 Physicochemical Changes of F oods during Frying Novel Evaluation Techniques and Effects of Process Parameter s. 9 Januari 2020 (11.25)

Andriyani, Y., Syahrumsah, H., dan Marwati. 2017. Studi Formulasi Jagung (Zea Mays L.) dan Tempe terhadap Nilai Gizi dan Sifat Mutu Sensoris Tortilla Chips. Jurnal Teknologi Pertanian Universitas Mulawarman 12(2):64-69

AOAC Internatonal. 2007. Official Methods of Analysis of AOAC International. 18th ed.. AOAC Internatonal Gaithersburg, MD 
Asmoro, N.W., Hartati, S., dan Handayani, C.B. 2017.Karakteristik Fisik dan Organoleptik Produk Mocatilla Chips dari Tepung Mocaf dan Jagung. Jurnal Ilmu Pangan dan Hasil Pertanian 1(1): 63-70

Astawana, M., Wresdiyati, T., Widowati, S., Bintari, S.H. 2013. Karakteristik Fisikokimia dan Sifat Fungsional Tempe yang Dihasilkan dari Berbagai Varietas Kedelai. Pangan 22(3): 241-252

Badan Pusat Statistik (BPS). 2016. https://www.bps.go.id/subject/53/tanamanpangan.html\#subjekViewTab3. 25 Februari 2020 (11:23)

Badan Standarisasi Nasional (BSN). 1992. SNI 01-2891-1992: Cara Uji Makanan dan Minuman. Badan Standarisasi Nasional. Jakarta

Badan Standarisasi Nasional (BSN). 2015. SNI 2886:2015: Makanan Ringan Ekstrudat. Badan Standarisasi Nasional. Jakarta

Chhabra, N., Kaur, A.dan Kaur, S. 2017. Development of Composite Tortilla Chips: An Approach With Improved Quality. The Pharma Innovation Journal 6(9): 514-520

Christian, Y. 2017. Pengaruh Jenis Kedelai (Glycine Max L.) dan Waktu Blanching terhadap Sifat Fisiko-Kimia dan Sifat Sensoris Susu Kedelai Bubuk. Jurnal Teknologi Pertanian Universitas Mulawarman 12(2): 45-52

Darmajana, D.A., Sholichah, E., Afifah, N., Luthfiyanti, R. dan Andriana, Y. 2015. Pemanfaatan Teknologi Tepat Guna dalam Penerapan Cleaner Productiondi Industri Kecil Pengolahan Tahu di Subang dan Sumedang. LIPI Press. Jakarta

Karneta, R., Kahfi, A.N.,dan Aluyah, C. 2018.Fortifikasi dari Kedelai (Glicine Max L Merr) pada Formula Tortilla Jagung. Prosiding Seminar Nasional Lahan Suboptimal Palembang. 18-19 Oktober: 465-472

Kaur, S.dan Aggarwal, P. 2017. Development of Maize-Potato Tortilla Chips: A Nutritious and Low Fat Snack Food. Journal of Pharmacognosy and Phytochemistry 6(4): 153-161

Kawas, M.L. dan Moreira, R.G. 2001. Characterization of Product Quality Attributes of Tortilla Chips During The Frying Process. Journal of Food Engineering 47: 97-107

Ochoa-Martinez, L.A., Castillo-Vazquez, K., Figueroa-Cardenas, J.D.D., Morales-Castro, J.dan Gallegos-Infante, J.A.2016. Quality Evaluation of Tortilla Chips Made with Corn Meal Dough and Cooked Bean Flour. Cogent Food \& Agriculture 2: 1-7

Rababah, T.M., Brewer, S.,Yang, W., Al-Mahasneh, M., Al-U'datt, M., Rababa, S.danEreifej, K. 2012.Physicochemical Properties of Fortified Corn Chips with Broad Bean Flour, Chickpea Flour or Isolated Soy Protein. Journal of Food Quality 35: 200-206

Ratnawati, L. Ekafitri, R. dan Desnilasari, D. 2019. Karakterisasi Tepung Komposit Berbasis Mocaf dan Kacang-Kacangan sebagai Bahan Baku Biskuit MP-ASI. Biopropal Industri 10(2):65-81

Ratnawati, L.dan Afifah, N. 2018. Pengaruh Penggunaan Guar Gum, CMC dan Karagenan terhadap Kualitas Mi yang Terbuat dari Campuran Mocaf, Tepung Beras dan Tepung Jagung. Pangan 27(1): 43-54

Rohmayanti, T., Novidahlia, N., dan Damayanti, I. 2019. Karakteristik Tortilla Chips dengan Penambahan Tepung Ampas Kecap. Jurnal Agroindustri Halal 5(1): 113-121

Syafutri, M.I.dan Lidiasari, E. 2014. Pengaruh Konsentrasi Penambahan Tepung Tempe terhadap Karakteristik Tortilla Labu Kuning. Jurnal Teknologi Industri dan Hasil Pertanian Volume 19(2): 289-296

Widaningrum, Widowati, S., dan Soekarto, S. T. 2005. Pengayaan Tepung Kedelai pada Pembuatan Mie Basah dengan Bahan Baku Tepung Terigu yang Distubtitusi Tepung Garut. Jurnal Pascapanen2(1): 41-48. 